\title{
Pendampingan Pengelolaan Sampah Di Bank Sampah Eltari, Cemorokandang, Kecamatan Kedungkandang, Kota Malang
}

\author{
Kgs Ahmadi ${ }^{1}$, Lorine Tantalu ${ }^{2}$, Nonok Supartini ${ }^{3}$, Edyson Indawan ${ }^{4}$, Imroatus Sholiqah ${ }^{5}$ \\ Universitas Tribhuwana Tunggadewi $1,2,3,4,5$ \\ kgs.ahmadi@yahoo.com ${ }^{1}$, lorine.tantalu@unitri.ac.id², nonik_76@yahoo.com², mankedlht@yahoo.com ${ }^{4}$, \\ imroatus230@gmail.com ${ }^{5}$
}

\begin{abstract}
The Eltari Waste Bank is one of the Malang Waste Banks under the guidance of the Malang City Environment Service. Located at Jalan Palmerah RT 02 RW 06, Cemorokandang, Kedungkandang District, Malang City, it provides a place for the process of collecting waste that has been sorted based on conditions and types of waste, both organic and non-organic. Not all residents have understood the importance of sorting waste by type, coupled with the not yet optimal use of nonorganic or plastic waste to become goods needed by the community. Through the waste management assistance process by the service team in the form of the introduction of efforts to recycle plastic packaging waste into mats and bags, it is able to increase the productivity of the Eltari Waste Bank. The introduction activity succeeded in attracting the interest of residents around the Waste Bank because in addition to being able to increase the livelihoods of local residents, it can also increase family income up to $25 \%$.
\end{abstract}

Keywords: eltari waste bank; assistenace; waste management.

\begin{abstract}
Abstrak
Bank Sampah Eltari menjadi salah satu Bank Sampah Malang dibawah binaan Dinas Lingkungan Hidup Kota Malang. Bertempat di Jalan Palmerah RT 02 RW 06, Cemorokandang, Kecamatan Kedungkandang, Kota Malang ini menyediakan tempat untuk proses penampungan sampah yang telah dipilah berdasarkan kondisi dan jenis sampah baik organik maupun non-organik. Tidak semua warga telah memahami pentingnya pemilahan sampah berdasarkan jenis, ditambah pula dengan belum optimalnya pemanfaatan sampah non-organik atau plastik tersebut untuk menjadi yang bermanfaat. Melalui proses pendampingan pengelolaan sampah oleh tim pengabdi dalam bentuk introduksi upaya daur ulang sampahb plastik kemasan menjadi tikar dan tas mampu meningkatkan produktivitas dari Bank Sampah Eltari. Kegiatan introduksi berhasil menarik minat warga sekitar Bank Sampah karena disamping mampu menambah mata pencaharian warga sekitar juga dapat meningkatkan pendapatan keluarga hingga mencapai $25 \%$.
\end{abstract}

Kata Kunci: bank sampah eltari; pendampingan; pengelolaan pampah. 


\section{A. PENDAHULUAN}

Bertambahnya penduduk memiliki potensi ikut bertambahnya volume sampah disuatu wilayah, umumnya wilayah kota. Pertumbuhan penduduk terjadi karena faktor peningkatan ekonomi masyarakat atau perpindahan penduduk dari desa ke kota. Sayangnya tidak semua orang peduli terhadap sampah, terutama pada sistem pengelolaan sampah. Sampai dengan saat ini, sebagian besar sampah ditimbun dan belum mendapat proses pengelolaan yang berarti (Yulianti dan Huda, 2018). Hal ini akan berdampak pada pengurangan ruang gerak wilayah serta berdampak negatif pada kesehatan lingkungan.

Pengelolaan dan pengolahan sampah memberikan nilai tambah sehingga sampah dapat diubah menjadi sesuatu yang bermanfaat. Sampah itu memiliki definisi sebagai semua bentuk padat baik organik maupun anorganik yang dihasilkan dari kegiatan manusia maupun hewan dan tidak digunakan atau bermanfaat bagi mereka (Saputro dkk., 2015). Undang-Undang No. 18 tahun 2008 mengatur dan didalamnya telah memuat perihal yang fokus pada perlunya perubahan pengelolaan sampah yang sebelumnya bersifat konvensional ke arah pengurangan dan upaya penanganan timbunan sampah dengan lebih efektif. Pengurangan sampah yang dimaksud diartikan dengan pengurangan dan pembatasan jumlah timbulan sampah khususnya dari ranah rumah tangga dan pasar dengan cara mendaur ulang serta memanfaatkannya kembali menjadi melalui kegiatan 3R yaitu Reduce, Reuse dan Recycle (Selomo dkk., 2016). Kegiatan ini akan semakin maksimal manakala masyarakat yang menghasilkan timbulan sampah memiliki kesadaran tinggi dalam memilah sampah.
Alternatif yang muncul manakala timbulan sampah kian tak terkendali di beberapa wilayah khususnya daerah perkotaan adalah dengan berdirinya Bank Sampah (Tomboelu dkk., 2021). Bank Sampah didirikan sebagai bentuk nyata kepedulian masyarakat lokal dalam menerapkan 3R untuk memilah sampah yang masih dapat dimanfaatkan. Bentuk kegiatan dari Bank Sampah bersifat social engineering untuk mengajarkan dan meningkatkan kesadaran masyarakat akan pengelolaan sampah dengan bijak dengan output mengurangi jumlah timbulan sampah di TPA (Hanifah, 2017). Peraturan Menteri Lingkungan Hidup RI Nomor 13 Tahun 2012 telah menjelaskan bahwa Bank Sampah didirikan untuk digunakan sebagai tempat memilah sekaligus mengumpulkan sampah untuk didaur ulang dan meningktakn nilai ekonomi. Hasil dari sampah yang dipilah sendiri oleh masyarakat nantinya dapat ditukarkan dengan besaran nominal tertentu sesuai kesepakatan. Melalui penukaran sampah tersebut dalam bentuk uang atau hal lain yang berharga diharapkan dapat meningkatkan kepedulain masyarakat terhadap timbulan sampah sekaligus meningkatkan taraf perekonomian rumah tangga (Kurnia, 2013). Hasil penelitian (Fitriasari dan Nurjannah, 2017) menunjukkan Bank Sampah memberikan pendapatan tambahan yang dapat sedikt membantu keuangan keluarga. Data statistik terkait dengan perkembangan pembangunan Bank Sampah di Indonesia di tahun 2012 menunjukkan bahwa hingga akhir bulan Mei 2012, jumlah pendapatan yang diperoleh dengan mengumpulan sampah yang dapat didaur ulang sebanyak $2.001 .789 \mathrm{~kg} / \mathrm{bulan}$ oleh 84.624 orang mampu mengumpulkan tabungan hingga maksimal $\mathrm{Rp}$. 3.182.281.100,- per bulan dari total 886 buah Bank Sampah (Samadikun dkk., 2017). 
Bank Sampah Eltari M230 merupakan salah satu Bank Sampah Unit (BSU) yang berdiri di Kota Malang, beralamatkan di Jalan Bendungan Palmerah RT 2 RW 06, Cemorokandang, Kecamatan, Kedungkandang, Kota Malang, Jawa Timur. Bank Sampah ini dikelola oleh Ibu Efrida Hartini dan tergabung dalam Bank Sampah Malang (BSM) binaan Dinas Lingkungan Hidup (DLH) Kota Malang. Hingga di Tahun 2021, Bank Sampah Eltari telah menghimpun kegiatan masyarakat di RW 06, Cemorokandang dalam bentuk pilahan sampah untuk dilanjutkan dalam bentuk tabungan emas.

\section{B. PELAKSAAAN DAN METODE}

Peraturan Menteri Lingkungan Hidup Nomor 13 Tahun 2012 terkait Bank Sampah memiliki ruang lingkup yang meliputi:

1. Persyaratan pendirian Bank Sampah, yaitu harus mempunyai bangunan berikut dengan sistem manajemennya.

2. Mekanisme Kerja dalam Bank Sampah, meliputi kegiatan pemilahan sampah, penyerahan sampah pilahan ke Bank Sampah oleh masyarakat, pengukuran berat sampah, dokumentasi tertulis terkait nama, jumlah sampah $(\mathrm{kg})$ dan berapa yang dihasilkan dari penjualan sampah yang dikumpulkan ke Bank Sampah, serta bentuk bagi hasil untuk sampah yang dijual antara pengumpul dan pelaksana di Bank Sampah jika ada.

3. Pelaksanaan kegiatan Bank Sampah, yang meliputi tetapan jam aktif kerja, pencatatan untuk hasil yang ditabung, beberapa dokumentasi tertulis yang memungkinkan dibutuhkan diantaranya buku tabungan, buku peminjaman uang, biaya jasa untuk pemungutan sampah, jenis sampah yang dikumpulkan, penetapan harga sampah, keadaan sampah saat datang, berat sampah minimum serta wadah dari sampah.

4. Pelaksana dalam Bank Sampah, dalam hal ini berperan sebagai fasilitator dalam proses pembangunan dan pelaksana kegiatan dalam Bank Sampah, diantaranya penyedia data untuk pengepul maupun pembeli sampah bagi bank sampah serta penyedia data terkait industri daur ulang sekaligus memberikan penghargaan dalam bentuk uang atau yang telah disepakati dengan masyarakat setempat

Ruang lingkup yang ada pada Bank Sampah Eltari Cemorokandang telah mengupayakan untuk mengadakan ke-empat faktor tersebut. Wilayah pengumpulan yang menjadi sasaran masyarakat pengepul adalah dari wilayah RW 06 Cemorokandang. Namun, beberapa kendala dihadapi dalam pelaksanaan kegiatan dalam Bank Sampah. Masalah yang dihadapi diantaranya:

1. Umumnya sampah yang dikumpulkan atau berada di wilayah Bank Sampah Eltari belum banyak dipilah sesuai jenis dan kondisinya.

2. Jenis sampah plastik atau sampah nonorganik masih belum optimal diolah.

Masalah yang dihadapi oleh Bank Sampah Eltari tersebut memerlukan upaya pendampingan terkait pengelolaan sampah, khususnya sampah non-organik di wilayah Cemorokandang,

Kecamatan Kedungkandang, Kota Malang, Jawa Timur. Melalui pendampingan terkat pengelolaan, altenatif untuk peningkatan nilai sampah daur ulang akan lebih meningkat dan semakin menumbuhkan kepedulian masyarakat terhadap upaya 3R pada sampah domestik yang ada.

Kegiatan ini dilaksanakan pada tanggal 10 Mei 2021 di Bank Sampah Eltari, Jalan $\begin{array}{llll}\text { Bendungan Palmerah RT } & 02 & \text { RW02 }\end{array}$ Cemorokandang, Kecamatan 
Kedungkandang, Kota Malang. Kegiatan pendampingan yang dilakukan oleh tim pengabdian kali ini mengupayakan untuk memberikan alternatif pengelolaan sampah non-organik berikut dengan upaya peningkatan pengelolaan sampah di Bank Sampah Eltari yaitu melalui kegiatan introduksi teknologi tepat guna untuk mengolah sampah non organik seperti plastik.

Sebelum diadakan kegiatan pendampingan, dilakukan survei dan wawancara terkait kegiatan berupa tahapan proses pelaksanaan didalam Bank Sampah Eltari, yaitu mulai dari (1) Penerimaan sampah, (2) Pengecekan kondisi sampah oleh pelaksana, (3) Pengukuran berat sampah, (4) Pencatatan hasil pengukuran dan nilai nominal yang dihasilkan dari sampah tersebut.

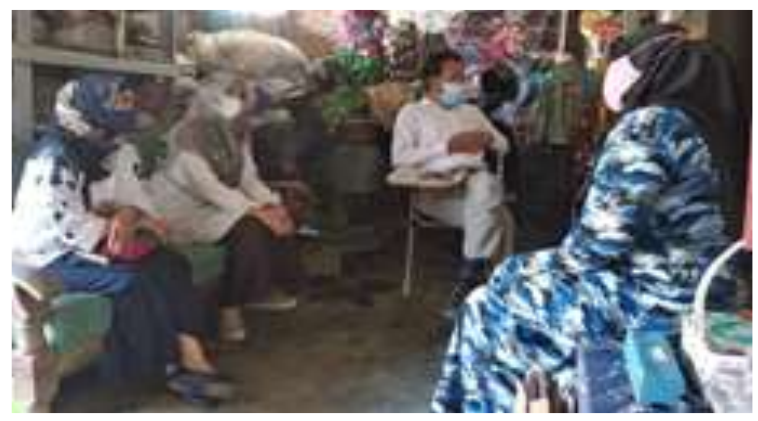

Gambar 1. Kegiatan wawancara tim pengabdi bersama Ketua Bank Sampah Eltari

Penglelolaan bank sampah secara umum mengikuti alur seperti pada Gambar 2 (Dewanti dkk., 2020). Demikian juga halnya pada Bank Sampah Eltari mengikuti alur yang sama. Akan tetapi pada tahapan pengelolaan sampah non organik untuk menjadi suatu produk bernilai belum berlangsung optimal.

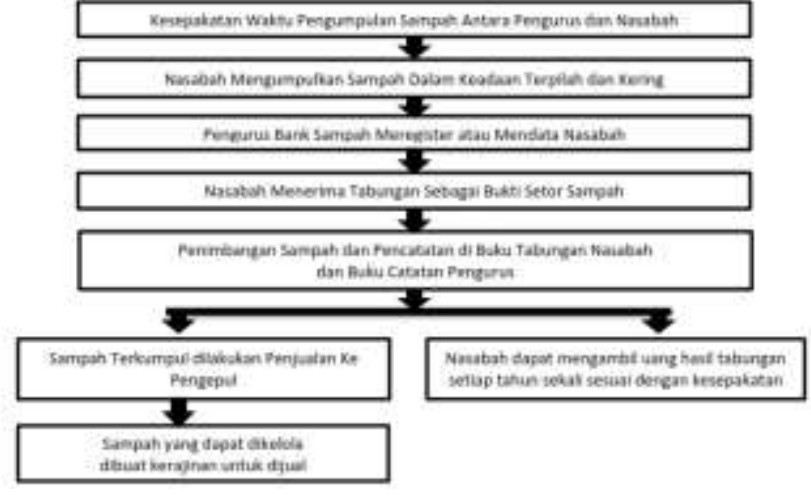

Gambar 2. Alur Proses Bank Sampah (Dewanti dkk, 2020)

Langkah selanjutnya adalah proses pendampingan berupa introduksi upaya daur ulang sampah non-organik menjadi produk bernilai. Proses introduksi tersebut dilakukan dengan memberikan pengarahan secara langsung kepada Ketua Bank Sampah Eltari untuk kemudian dilanjutkan kepada warga binaan khususnya di wilayah Cemorokandang, Kecamatan Kedungkandang, Kota Malang. Introduksi ini telah dikaji lebih lanjut oleh tim pengabdi dalam bentuk analisis SWOT untuk diterapkan di Bank Sampah Eltari.

Tim pengabdi melakukan kunjungan ke Bank Sampah Eltari berdiskusi dan menggali masalah yang dihadapi Bank Sampah Eltari (Gambar 3). Hasil perumusan menjadi alternatif pemecahan masalah utamanya dalam pengelolaan sampah non organik.

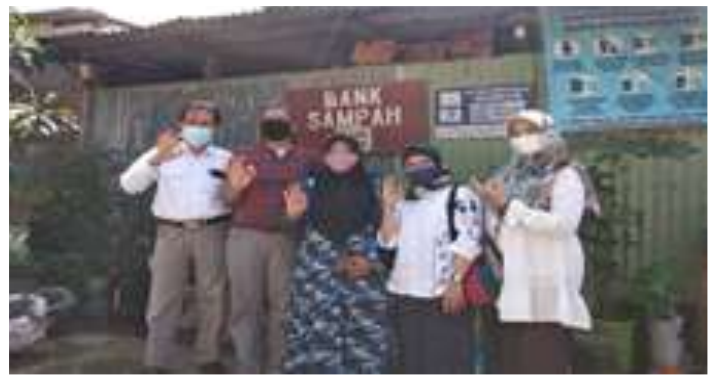

Gambar 3. Tim Pengabdi bersama Pengelola Bank Sampah Eltari 


\section{HASIL DAN PEMBAHASAN}

Masalah yang dihadapi oleh pelaksana Bank Sampah Eltari yang pertama yaitu terkait dengan tidak seragamnya kondisi sampah yang dikumpulkan pada Bank. Untuk hal ini, langkah yang harus diterapkan adalah perluanya tindakan tegas terkait sampah yang diterima oleh pengepul. Pihak pengepul harus menerima jika sampah yang dikumpulkan harus dikembalikan karena tidak layak untuk diterimakan di Bank Sampah dan perlu dilakukan pemilahan kembali oleh pengepul. Gambar 3 menunjukkan bahwa pelaksana Bank Sampah sedang memeriksa sampah yang dikumpulkan oleh warga. Setelah sampah dinyatakan layak, baru dilakukan penimbangan dan pencatatan.

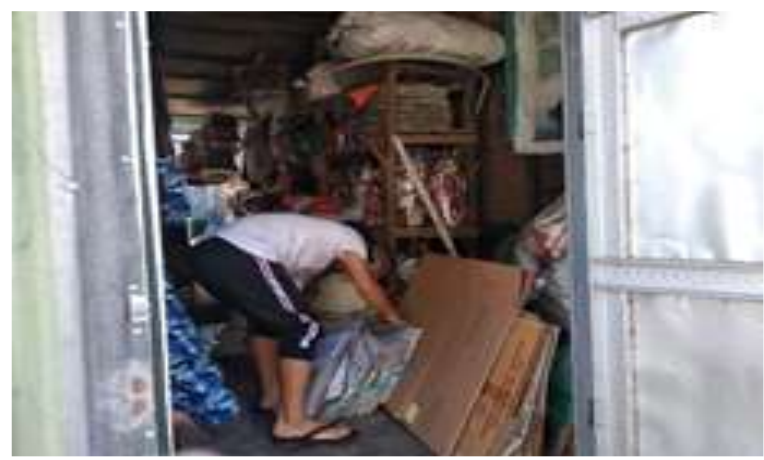

Gambar 4. Pemeriksaan sampah oleh pelaksana Bank Sampah Eltari.

Upaya yang paling memungkinkan untuk diterapkan dalam pengelolaan sampah nonorganik di Bank Sampah Eltari adalah dengan mendaur ulang sampah plastik yang terkumpul untuk dijadikan barang layak jual. Sampah plastik yang berasal dari kemasan minuman sachet atau detergen berpeluang untuk dijadikan produk sepert tikar dan tas. Bersama dengan Ketua Bank Sampah Eltari mengupayakan kegiatan daur ulang kemasan kopi untuk dijadikan tikar ibadah atau tikar rumah tangga. Metode yang digunakan masih konvensional yaitu dengan digunting secara manual oleh tenaga manusia untuk dijadikan bahan sulam tikar. Kegiatan yang dilakukan cukup mengundang banyak perhatian warga untuk membantu membuat potongan sulam tikar dari kemasan kopi. Melalui metode ini, untuk menghasilkan 1 tikar ukuran berukuran 40 x $90 \mathrm{~cm}$ memerlukan waktu 2 hari. Harga tikar tersebut mencapai Rp. 200.000 rupiah. Dari jumlah penduduk yang membantu, ratarata dari hasil penjualan produk tersebut mampu menambah pendapatan mereka hingga $25 \%$ dari total pendapatan keluarga. produk disajikan pada Gambar 5.

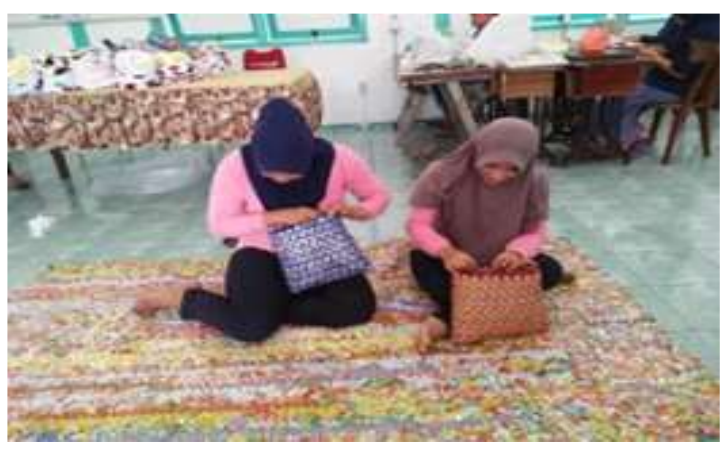

Gambar 4. Kegiatan produksi tikar dan tas dari sampah non-organik.

Langkah pertama untuk penjualan adalah dari jaringan sosial media ibu-ibu dasawisma di area RW 06 Cemorokandang, Kecamatan Kedungkandangm Kota Malang. Analisis SWOT untuk kegiatan introduksi upaya daur ulang untuk sampah non-organik di Bank Sampah Eltari adalah sebagai berikut :

Tabel 1. Analisis SWOT Upaya daur ulang sampah non-organik menjadi barang kebutuhan rumah tangga

\begin{tabular}{ll}
\hline Strength (Kekuatan) & $\begin{array}{l}\text { Weakness } \\
\text { (Kelemahan) }\end{array}$
\end{tabular}

- Bank Sampah Eltari telah memiliki lahan sebagai bank Sampah seluar $4 \times 7$ $\mathrm{m}$

- Memiliki tim pelaksana yang kompeten di bidang pengelolaan sampah

\section{- Kepedulian} masyarakat terkait kondisi sampah belum optimal

- Teknologi persiapan bahan sulam dari sampah non-organik yang 


\begin{tabular}{lrl}
\hline - Telah bermitra & masih \\
dengan BUMN & konvensional \\
Pegadaian sebagai & Pemasaran produk \\
bentuk reward bagi & $\begin{array}{l}\text { Pemasar daur ulang } \\
\text { pengepul sampah } \\
\text { masih } \\
\text { untuk dijadikan }\end{array}$ & $\begin{array}{l}\text { mengandalkan } \\
\text { tabungan emas }\end{array}$ \\
- Memiliki pengepul media skala \\
tetap untuk sampah \\
non-organik di \\
wilayah RW 06 \\
Cemorokandang, \\
Kedungkandang, \\
Kota Malang
\end{tabular}

\begin{tabular}{|c|c|}
\hline ty (Pelu & 17re \\
\hline $\begin{array}{l}\text { Melalui jejaring } \\
\text { Bank Sampah Eltari } \\
\text { dibawah binaan } \\
\text { DLH dapat } \\
\text { meningkatkan } \\
\text { jumlah pemasaran } \\
\text { produk berbahan } \\
\text { dasar daur ulang } \\
\text { sampah non-organik } \\
\text { Tersedianya layanan } \\
\text { toko online non- } \\
\text { bayar untuk } \\
\text { mendaftarkan } \\
\text { produk } \\
\text { dihasilkan }\end{array}$ & $\begin{array}{l}\text { - Duplikasi produk } \\
\text { yang dihasilkan } \\
\text { oleh Bank Sampah } \\
\text { Eltari karena belum } \\
\text { dilakukan } \\
\text { pendaftaran merek } \\
\text { dagang. } \\
\text { - Ketidak siapan } \\
\text { bahan sulam ketika } \\
\text { tenaga manusia } \\
\text { menjadi sumber } \\
\text { daya utama untuk } \\
\text { mendapat bahan } \\
\text { sulam. }\end{array}$ \\
\hline
\end{tabular}

Hasil analisa SWOT tersebut menunjukkan perlunya pengembangan teknologi tepat guna untuk membantu mempersiapkan bahan dasar sulam dari sampah non-organik, seperti mesin pencacah. Tahapan ini akan mengurangi waktu produksi untuk menghasilkan produk yang diinginkan, khususnya jika mengupayakan agar produk ini diperjual belikan dengan segmen yang lebih luas. Seperti halnya yang disampaikan oleh (Rahman dkk., 2020), salah satu bentuk kegiatan yang dapat meningkatkan nilai dari sampah adalah dengan menerapkan teknologi tepat guna untuk sampah spesifik.
(Hariansyah dan Eldine, 2016) menambahkan bahwa kegiatan ini akan semakin kuat manakala terjalin kemitraan antara institusi pendidikan dengan mitra pengelolaan sampah.

\section{PENUTUP}

\section{Simpulan}

Kegiatan pendampingan ini dihasilkan ketepatan sasaran terkait pengelolaan sampah non-organik dengan tujuan pendampingan, yaitu upaya mengurangi timbulan sampah non-organik menjadi barang lebih bernilai. Melalui upaya daur ulang sampah nonorganik berupa kemasan kopi menjadi produk rumah tangga seperti tikar dan tas mampu menambah jumlah pekerja dan pendapatan warga sekitar Bank Sampah Eltari. Walaupun setidaknya memerlukan waktu sedikit agak lama untuk menghasilkan produk karena metode yang masih konvensional, tidak menyurukan niat warga sekiatr Bank Sampah Eltari untuk menghasilkan produk lebih bernilai dari sampah.

Melalui kegiatan rekayasa sampah di Bank Sampah Eltari semakin meningkatkan kepedulian masyarakat utamanya dalam memilah sampah dengan menerapkan 3R. Dampak yang paling signifikan adalah mengurangi jumlah sampah yang dibuang di TPA. Hal yang paling menarik dengan kegiatan daur ulang sampah non-organik menjadi barang kebutuhan rumah tangga adalah dengan semakin bertambahnya tabungan warga di Bank Sampah Eltari dalam bentuk emas dengan menyetorkan dana yang didapatkan dari kegiatan persiapan sulam tikar atau tas kepada pelaksana Bank Sampah Eltari.

\section{Saran}

Pengelola bank sampah Eltari dapat menjaga keberlanjutan teknologi pengolahan sampah ang telah diberikan 


\section{Ucapan Terima Kasih}

Terima kasih diucapkan kepada Ketua Bank Sampah Eltari, Ibu Efrida Hartini dan Bapak Yusuf yang senantiasa tulus dan berdedikasi tinggi dalam menggerakkan kegiatan bank Sampah Eltari di wilayah Cemorokandang, Kecamatan

Kedungkandang, Kota Malang.

\section{E. DAFTAR PUSTAKA}

Dewanti, M.Purnomo, E.P.dan Salsabila, L. (2020). Analisa efektifitas bank sampah sebagai alternatif pengelolaan sampah dalam mencapai smart city di kabupaten kulon progo. Publisia: Jurnal Ilmu Administrasi Publik,5 (1).

Fitriasari, F. dan Nurjannah, D. (2017). Analisis Pengaruh Bank Sampah Malang (BSM) terhadap Pendapatan Masyarakat Kota Malang. Business Management Journal,12 (1):53-70.

Hanifah, U. (2017). Optimalisasi Pengelolaan Bank Sampah untuk Mengurangi Volume Sampah Non Organik Sekaligus Menghasilkan Nilai Ekonomis bagi Masyarakat Kelurahan Krajan Kabupaten Madiun. Engagement: Jurnal Pengabdian Kepada Masyarakat,1 (2):198-208.

Hariansyah, M. dan Eldine, A. (2016). Pengembangan Teknologi Tepat Guna Dalam Pengelolaan Sampah Plastik. Neraca Keuangan,11 (2):31-40.

Kurnia, W.A. (2013). Pahlawan Sampah dari Wiyung. Jakarta: Dirjen Cipta Karya.

Rahman, A.Y.Setiawan, F.W.dan Hananto, A.L. (2020). Aplikasi Teknologi Tepat Guna Untuk Umkm Pengolahan Sampah Organik Sebagai Pakan Cacing. Panrita Abdi - Jurnal Pengabdian pada Masyarakat,4 (2):205.
Samadikun, B.S.Handayani, D.S..dan Laksana, M.P. (2017). Revitalisasi Pengelolaan Bank Sampah Di Palabuhanratu. Jurnal Presipitasi: Media Komunikasi dan Pengembangan Teknik Lingkungan,14 (2):68.

Saputro, Y.E.Kismartinidan Syafrudin (2015). Pengelolaan Sampah Berbasis Masyarakat Melalui Bank Sampah. Indonesian Journal of Conservation, 4 (1):83-94.

Selomo, M.Birawida, A.B.Mallongi, A.dan Muammar (2016). Bank Sampah Sebagai Salah Satu Solusi Penanganan Sampah Di Kota Makassar. Jurnal MKMI,12 (4):232-240.

Tomboelu, V.E.Christiani, L.Vania, G.T, G.O.L, M.B.C.Pratiwi, J.Hapuk, G.K.Pradityo, I.Bupu, G.M.Christiani, L.Galih, B.dan Pradana, V. (2021). Kesenian dan Kebuda yaan Desa Margosari , serta Pengembangan Bank Sampah,1 (1):1-7.

Yulianti dan Huda, R. (2018). Manajemen Pengelolaan Sampah Studi Kasus di Bank Sampah Tirtarona Tlogomas Kota Malang. JPM (Jurnal Pemberdayaan Masyarakat),3 (2):294-299. 